\title{
Peran Manajemen Hubungan Masyarakat Dalam Meningkatkan Mutu Pendidikan Di MAN 2 Lombok Timur
}

\author{
Riyan Noviantiaini ${ }^{1}$, Sri Harmonika ${ }^{2}$ \\ 1riyannoviantiaini@gmail.com, ${ }^{2}$ sriharmonika847@gmail.com, \\ 1, 2 Manajemen Pendidikan Islam, STAI Darul Kamal, Lombok Timur, Indonesia
}

\begin{abstract}
Abstrak
Penelitian ini bertujuan untuk mengetahui peran manajemen hubungan masyarakat dalam meningkatkan mutu Pendidikan di MAN 2 Lombok Timur.Jenis penelitian ini merupakan jenis penelitian kualitatif dengan menggunakan deskriptif, subyek peneliti kepala sekolah,wakasek kehumasan dan guru-guru bidang study lainnya. Pengumpulan data menggunakan metode wawancara, observasi, dan dokumentasi. Data yang terkumpul kemudian dianalisis melalui reduksi data, penyajian data, dan menarik kesimpulan. Untuk menjamin keabsahan data peneliti ini menggunakan Teknik triangulasi sumber dan metode. Hasil penelitian ini menunjukan bahwa peran humas dalam rangka meningkatkan mutu Pendidikan di MAN 2 Lombok Timur di laksanakan sesuai prosedur yang ditetapkan. Akan tetapi dalam pelaksanaannya belum dapat dilakukan secara terstruktur, hal ini dapat dilihat dari beberapa peran humas yaitu: peran humas sebagai komunikator, peran humas sebagai Pembina hubungan, dan peran humas sebagai pembentuk peningkatan mutu sekolah. Media humas yang digunakan MAN 2 Lombok Timur masih dalam bentuk kalimat yang sifatnya informatif saja dan belum adanya unsur persuasive yang terdapat pada brosur MAN 2 Lombok Timur. Kemudian kendala yang dihadapi humas dalam menigkatkan mutu Pendidikan adalah 1. Peran humas belum berfungsi secara maksimal karna pengurus umas mempunyai fungsi ganda yaitu merangkap sebagai guru mata pelajaran. 2. Terbatasnya waktu yang dimiliki pengurus humas yang kadang tidak dapat melayani publik eksternal secara maksimal. 3. Ketidakpuasan publik internal dengan hasil kerja humas . sasaran hubungan masyarakat adalah publik internal yaitu seluruh warga sekolah yang meliputi kepala sekolah, guru, karyawan, siswa-siswi MAN 2 Lombok Timur. Publik eksternal meliputi masyarakat. Upaya humas untuk mengatasi kendala tersebut adalah pembuatan agenda pada setiap pengurus humas dapat menjalankan dengan baik tugas sebagai humas dan peran sebagai guru.
\end{abstract}

Kata kunci : Manajemen hubungan masyarakat, Mutu Pendidikan.

\section{Pendahuluan}

Salah satu upaya sekolah dalam memperkenalkan dan meningkatkan mutu pendidikan kepada masyarakat yakni melalui manajemen hubungan masyarakat 
(humas). Setiap kegiatan dalam organisasi membutuhkan manajemen, begitu juga dalam kegiatan hubungan masyarakat (HUMAS) atau public relation di lembaga pendidikan. hubungan masyarakat (humas) secara umum adalah salah satu bagian dari organisasi yang berfungsi untuk melakukan intraksi, hubungan, dan kerjasama dengan masyarakat yang terkait dengan organisasi tersebut. Humas merupakan singkatan dari hubungan masyarakat atau dalam bahasa inggris disebut dengan publik relation (PR) yang bertanggungjawab dalam membangun dan mempertahankan repotasi, citra dan komunikasi yang baik dan bermanfaat antara komunikasi dan publik, dalam dunia bisnis, fungsi humas kerap dikaitkan dengan marketing, padahal sangat berbeda. Sebagai fropesi bidang humas nantinya membantu mendidik, memberikan informasi, membangkitkan ketertarikan masyarakat, merencanakan strategi untuk meraih, simpati hingga membuat masyarakat mengerti dalam situasi tertentu. Bentuk komunikasi berencana baik kedalam maupun ke luar organisasi dengan publiknya untuk mencapai tujuan khusus, yakni pengertian bersama. ${ }^{1}$

Hasil observasi awal MAN 2 Lombok Timur sebagai lembaga pendidikan telah berhasil mewujudkan visi dan misinya dengan sangat baik, MAN 2 Lombok Timur telah mendapatkan kepercayaan yang baik dari masyarakat, salah satu buktinya peserta didik yang mendaftar setiap tahunnya melebihi jumlah yang telah ditargetkan serta peserta didiknya dapat berprestasi. Melihat realitas tersebut tidak mungkin terlepas dari pengaturan manajemen yang baik dan terarah pada sekolah tersebut. Keberhasilan MAN 2 Lombok Timur memfungsikan kerjasama tersebut, tidak lepas dari ruang lingkup manajemen humasnya, dengan menjaga dan meningkatkan hubungan baik dengan masyarakat. MAN 2 Lombok Timur tetap dipercaya sebagai sekolah favorit yang berkwalitas baik, unggul, mampu menghasilkan lulusan yang lebih kompeten berdaya saing dengan sekolah lulusan yang lain. Hal ini dalam rangka untuk memajukan mutu

${ }^{1}$ Frank Jeffkins (1986), dalam (Publik Relation. Humas - Publik Relation). Jakarta: Erlangga, 2004. Lib.UI. id> Detail. Blogspot.com 
sekolahnya. Berdasarkan fenomena di atas maka peneliti tertarik untuk meneliti lebih dalam tentang "peran manajemen hubungan masyarakat dalam meningkatkan mutu pendidikan di sekolah MAN 2 Lombok Timur.

\section{Kajian pustaka}

Manajemen hubungan masyarakat merupakan komunikasi dua arah antara organisasi dengan publik (masyarakat) secara timbal balik dalam rangka mendukung fungsi dan tujuan manajemen dengan meningkatkan pembinaan kerja sama serta pemenuhan kepentingan bersama². Hubungan masyarakat dengan pendidikan sangat bersifat korelatif, bahkan seperti ayam dengan telurnya. Masyarakat maju karena pendidikan, dan pendidikan yang maju hanya akan ditemukan dalam masyarakat yang maju pula ${ }^{3}$. Jelas bahwa pada hakikatnya keterlibatan masyarakat mempunyai peran yang cukup besar bagi kesuksesan suatu organisasi, untuk itulah bagi setiap organisasi perlu meningkatkan kerjasama yang baik dengan masyarakatnya sehingga keberhasilan akan diraih sesuai dengan harapan. Adapun peran humas di lembaga pendidikan antara lain adalah membina hubungan harmonis kepada publik internal (dalam lingkungan lembaga pendidikan) seperti dosen, guru, tenaga administrasi, dan siswa. Dan hubungan kepada publik eksternal atau diluar lembaga pendidikan seperti, orang tua siswa dan diluar lembaga pendidikan. Membina komunikasi dua arah kepada publik internal dan publik ekternal dengan menyebarkan pesan, informasi, dan publikasi hasil penelitian dan berbagai kebijakan-kebijakan yang telah di tetapkan pimpinan, mengidentifikasi dan menganalisis suatu opini atau berbagai persoalan.

Mutu pendidikan adalah derajat keunggulan dalam pengelolaan pendidikan secara efektif dan efesien untuk melahirkan keunggulan akademik dan ekstrakulikuler

2 M Akhsin Mansyur dan M. Linggar Anggoro, (2011) “Teori Dan Profesi Kehumasan”, (Jakarta:Bumi Aksara,2001), hal 1

3 Muhammad Noor Syam (1986:199), dalam Bukunya Filsapat Pendidikan Pancasila. , https://id.m.Wikipedia,Organisasi.com. 
pada peserta didik yang dinyatakan lulus untuk satu jenjang pendidikan atau menyelesaikan program pembelajaran tertentu, sehingga mutu pendidikan yang dimaksudkan disini adalah kemampuan lembaga pendidikan dalam mendayagunakan sumber-sumber pendidikan untuk meningkatkan kemampuan belajar seoptimal mungkin. ${ }^{4}$

\section{Metode penelitian}

Penelitian ini dilaksanakan di MAN 2 Lombok Timur terletak di kecamatan wanasaba kabupaten Lombok Timur Provinsi Nusa Tenggara Barat, dilihat dari kedudukannya secara astronomis MAN 2 Lombok Timur kecamatan Wanasaba memiliki batas administratif yaitu sebelah utara berbatasan dengan pemukiman penduduk, sebelah selatan berbatasan dengan pemukiman padat penduduk, sebelah barat berbatasan dengan persawahan dan sebelah timur berbatasan dengan persawahan dan pemukiman penduduk.Dengan desain kualitatif deskriptif, data dikumpulkan melalui observasi, wawancara dan dokumentasi.Subjek penelitian adalah kepala sekolah, dewan guru dan waka hubungan masyrakat, tokoh masyarakat dan wali murid. Pada penelitian ini instrumen penelitiannya adalah peneliti sendiri sebagai instrument utama, kemudian pedoman wawancara dan pedoman observasi. Analisis data pada penelitian ini mengikuti model Milles dan Huberman yang terdiri darireduksi data, penyajian data dan penarikan kesimpulan.Untuk memperkuat keabsahan data hasil temuan serta mempertahankan validitas data penelitian, peneliti menggunakan empat kriteria sebagai acuan standar validitas seperti yang disarankan oleh Licoln dan Guba yang meliputi kredibilitas, keteralihan, katergantungan dan kepastian ${ }^{5}$.

${ }^{4}$ Ace Suryadi dan H.A.R. Tilaar, Analisis Kebijakan Pendidikan Suatu Pengantar, (Bandung: Remaja Rosdakarya 1993 )., ha159.

${ }^{5}$ Lexy J. Meleong, Metodologi Penelitian Kualitatif, (Bandung: Remaja Rosdakarya, 2006) , 324. 


\section{Pembahasan}

Manajemen hubungan masyarakat yang diterapkan di MAN 2 Lombok Timur meliputi beberapa aspek diantaranya .

1. Peran manajemen hubungan masyarakat di sekolah MAN 2 Lombok Timur dalam upaya meningkatkan mutu Pendidikan diwujudkan melalui beberapa kegiatan yaitu

a) Peran humas sebagai komunikator untuk public internal, b) peran humas sebagai komunikator untuk public ekternal. Jadi jelas Peran humas yakni sebagai penghubung, perantara komunikasi antara sekolah dengan masyarakat. publik relations yang berarti hubungan sekolah dengan masyarakat sebagai hubungan timbal balik antara suatu organisasi sekolah dan masyarakat ${ }^{6}$

2. Proses humas dalam meningkatkan mutu Pendidikan di sekolah MAN 2 Lombok Timur meliputi kegiatan bakti sosial, dan Partisipasi dalam masyarakat.

3. Kendala humas yang dihadapi sekolah MAN 2 Lombok Timur dengan stekholdernya adalah 1) fungsi humas belum berfungsi secara maksimal karna pengurus humas mempunyai fungsi ganda yaitu merangkap sebagai guru mata pelajaran. 2) terbatasnya waktu yang dimiliki pengurus humas yang kadang-kadang tidak dapat melayani publik eksternal secara maksimal, 3) ketidakpuasan publik internal dengan hasil kerja humas

\section{Kesimpulan}

Setelah melakukan penelitian dan analisis data dari hasil penelitian, maka ada tiga kesimpulan yang sesuai dengan fokus penelitian yang dapat diambil dalam penelitian, yaitu:

1. Peran manajemen hubungan masyarakat di sekolah MAN 2 Lombok Timur dalam upaya meningkatkan mutu Pendidikan diwujudkan melalui beberapa kegiatan yaitu untuk publik internal dan eksternal adalah sebagai berikut: a) Peran humas sebagai

${ }^{6}$ Elfridawati Mai Dhuhani (2016), Dalam M Linggar Anggora, teori dan profesi kehumasan serta aplikasinya diindonesia, (Jakarta : Bumi Aksara 2000), hal 2 
komunikator untuk public internal, b) Peran humas sebagai komunikator untuk publik ekternal

2. Proses humas dalam meningkatkan mutu Pendidikan di sekolah MAN 2 Lombok Timur meliputi kegiatan bakti sosial, dan Partisipasi dalam masyarakat.

3. Kendala humas yang dihadapi sekolah MAN 2 Lombok Timur dengan stekholdernya adalah 1) fungsi humas belum berfungsi secara maksimal karna pengurus humas mempunyai fungsi ganda yaitu merangkap sebagai guru mata pelajaran. 2) terbatasnya waktu yang dimiliki pengurus humas yang kadang-kadang tidak dapat melayani publik eksternal secara maksimal, 3) ketidakpuasan publik internal dengan hasil kerja humas.

\section{Daftar Refrensi}

Frank Jeffkins (1986), dalam (Publik Relation. Humas - Publik Relation). Jakarta: Erlangga, 2004. Lib.UI. id> Detail. Blogspot.com

M Akhsin Mansyur dan M. Linggar Anggoro, “Teori Dan Profesi Kehumasan" ,(Jakarta:Bumi Aksara,2001).

Muhammad Noor Syam (1986:199), dalam Bukunya Filsapat Pendidikan Pancasila. , https://id.m.Wikipedia,Organisasi.com.

Ace Suryadi dan H.A.R. Tilaar, Analisis Kebijakan Pendidikan Suatu Pengantar, (Bandung: Remaja Rosdakarya 1993 ).

Lexy J. Meleong, Metodologi Penelitian Kualitatif, (Bandung: Remaja Rosdakarya, 2006).

Elfridawati Mai Dhuhani (2016), Dalam M Linggar Anggora, teori dan profesi kehumasan serta aplikasinya diindonesia, (Jakarta : Bumi Aksara, 2000). 